\title{
Collective Licensing of Copyright: Options for Competitive Reform
}

\author{
Jeremy Thorpe
}

\begin{abstract}
$\mathrm{C}$
OPYRIGHT law usually lags behind technological developments and changing market circumstances. It is high time that Australia's Copyright Act 1968 reflected the development of copyright collecting societies.

Copyright was originally formulated in an age when mass production was unknown and the geographic distribution of the copyrighted material was limited. In those circumstances, since authors were able to enforce their copyrights individually, there was little need for collective enforcement.

Copyright collecting societies have emerged as technological developments have made it harder for individuals to monitor and enforce their rights. The members of a copyright collecting society license their copyrights to the society, which in turn licenses the copyrighted material, and collects and distributes royalties, on behalf of the copyright owners.

Considerable concern has been expressed, especially by small businesses, about the power of collecting societies (HRSCLCA, 1997a:5-6). As a result, the Commonwealth House of Representatives Standing Committee on Legal and Constitutional Affairs (HRSCLCA) is considering the efficacy of the regulation of collecting societies. In this article it is argued that copyright collecting societies should be regulated in a manner consistent with the competitive regulatory regime that applies to other sectors of the economy.
\end{abstract}

\section{A Framework for Assessing Copyright Laws}

While often conceived of as a form of natural right, copyright is better understood as an economic tool (Drahos, 1996; ORR, 1995). It exists to attempt to correct market failures inherent in the production of intellectual and creative works, and hence facilitate the optimal level of creativity.

Copyright law 'protects the property rights of authors, composers and artists as an incentive to creative activity ... and in terms of economics, gives the copyright owner a temporary monopoly on the original work' (Dnes, 1996:33). It is important that the monopoly should be temporary, and limited to those circumstances in which the creative activity would not otherwise have occurred: 
intellectual property rights are justified only by the need to overcome failures of the market economy in producing creative works; unauthorised uses are prohibited only to the extent necessary to promote the correction of market failure and the efficient production of intellectual works. (Hadfield, 1992:5)

Given that copyright protection is a legislative grant of market power, it is appropriate to analyse the regulation of collecting societies in accordance with the framework agreed to by the Commonwealth, State and Territory governments in clause 5(1) of the Competition Principles Agreement (COAG, 1995):

The guiding principle is that legislation ... should not restrict competition unless it can be demonstrated that:

(a) the benefits of the restriction to the community as a whole outweigh the costs; and

(b) the objectives of the legislation can only be achieved by restricting competition.

This places the burden on those who benefit from the legislative grant of market power inherent in copyright to demonstrate that such power is in the public interest.

\section{Concerns about Collective Licensing}

In many cases, individual licensing of copyright is impossible because of the high monitoring and transaction costs involved. The distribution of copyrighted material worldwide often makes it impossible for artists to detect breaches of their copyright. Similarly, the costs become excessive if artists have to negotiate with many potential users. Copyright collecting societies have developed as a modern means to overcome these problems. 1 Six such societies exist in Australia.

Businesses have expressed two kinds of concern to the HRSCLCA (1997b). The first, and the more common, is alleged double-dipping by authors: for example, a singer or a song-writer who has already received royalties from a radio station may be reimbursed again when a shop owner listens to the performance over the radio. The second concern is that, although a licence may be justified, its price may be excessive.

The first concern has no weight as a matter of law, and little weight as a matter of policy. So-called double-dipping can be justified as a risk-sharing mechanism that aids the dissemination of copyrighted material. By providing authors with rights at multiple stages (for example, when a compact disc is sold to a radio station, and when it is played over the radio) the Copyright Act enables authors to share the

\footnotetext{
1 The move towards greater recognition of moral rights in Australia (see Clode, 1998) does not sit comfortably with the role played by collecting societies, since if collecting societies grant licences to anyone who is prepared to pay for them, this appears to convert the exclusive rights under the Copyright Act to mere rights of remuneration.
} 
risks by lowering the price of the initial sale licence (hence encouraging uptake), and then earning income later. The second concern, however, is more serious. It arises because copyright collecting societies employ actual or potential anti-competitive means to achieve their objectives. Copyright collecting societies bring together parties who would normally be competitors. This enables creators to discourage users from purchasing other material (tying), and to jointly determine prices for the copyright material (price-fixing) (Treasury, 1996:63).

This anti-competitive conduct raises the price of the work above that which would otherwise be charged and, as a corollary, results in a decrease in use of the copyrighted work. As copyright material has value only to the extent to which it is used, the broader diffusion and use of intellectual property adds value without adding significantly to costs. The collecting societies' restriction of the diffusion and use of intellectual property goes some way towards explaining why low-quality material ('elevator music' or 'muzak') is used in locations where use of original material may be preferred.

In addition, some collective licensing practices, particularly the licensing of all an author's rights to one person or organisation ('blanket licences'), discourage direct commissioning of works. While the majority of individually commissioned works in Australia are created by Australians, collectively licensed material is mostly foreign. Thus, regulation to restrict blanket licences should encourage the use of material created by Australians.

\section{How Collecting Societies Operate}

From the perspective of copyright owners, the current system of collecting societies appears quite reasonable. The six collecting societies are broadly aligned with the different classes of right holders; for example, the Phonographic Performance Company of Australia licenses the broadcasting and public performance of sound recordings owned by record companies, while the Copyright Agency Limited provides licences with respect to educational copying and journalists' rights. The Simpson Report on the operations of collecting societies clearly endorsed this logic and found no evidence that the number of societies should be reduced (Simpson, 1995:section 2.6).

From the user's perspective, however, the number and diversity of collecting societies appear slightly less practical. Of particular concern is the relative proliferation of collecting societies that license different rights for different purposes; indeed, Australia appears to have more collecting societies than any other Western country (Lester \& Faulder, 1989:108). This means that a business that requires more than one licence is likely to have to approach more than one collecting society; cooperation between collecting societies remains limited and the one-stop-shop is not a real option. International practices demonstrate that such a fragmented system is not necessary (Matsuoka, 1989:50). The multiplicity of societies appears to create significant complexity for non-intensive users of copyright (such as the majority of small businesses), even though the principal rationale of copyright col- 
lecting societies is that they reduce transaction costs for both copyright owners and users.

A solution to this problem is to reduce the points of contact that a small business must deal with in respect of copyright licensing. This can be achieved by regulating to encourage the emergence of competing 'one-stop-shop' collecting societies. Again, international evidence suggests that this proposal is feasible (ACCC, 1996:26). The Simpson Report, however, is scathing of such a suzgestion:

Given the frequently expressed concern about the power of societies, it is perhaps surprising that there is also a frequently expressed opinion tha: there are too many societies and that they would achieve greater efficiency by amalgamating and sharing administrative expenses. The views are in direct conflict. ... there is probably little cost advantage in the amalgamation of the existing societies. Rather, it is recommended that there be a multiplicity of societies so that individual societies can represent the disparate interests of the separate groups of rights owners. This is more likely to ensure the equitable representation of members' rights and promote a competitive environment. (Simpson, 1995: section 2.6)

Simpson's criticism is misdirected. Simpson makes the common mistake of assuming that because copyright provides market power to encourage the production of the work, such power should also be provided to facilitate the distribution of the copyright. As the Hilmer Report noted, it is important to limit the existence of market power solely to those elements where it is necessary, and introduce competition at every other stage (Hilmer, 1993:193).

While it is necessary to provide some form of market power to address the underproduction of creative works that would occur without copyright protection, there is no compelling reason to sanction market power over the distribution of the copyrighted works. Figure 1 demonstrates the social benefits from the introduction of protection through the legislative grant of market power in the form of copyright, and the subsequent benefit of ensuring that competition exists in distribution of the copyrighted work.

Without the copyright protection provided by a legislative grant of market power, only $\mathrm{Q} 0$ of copyrighted works would be created by authors (ORR, 1995:13$15,43-50)$. While some of $\mathrm{Q} 0$ may be sold at relatively high prices, the public's ability to copy the work means that there may only be a single (or at least very few) sales because the remaining consumers have an incentive, absent any intellectual property, technological or contractual protection, to produce $\left(Q^{*}\right.$ minus $\left.Q 0\right)$ copies and pay nothing to the authors in return.

Once copyright protection is granted, each person has a monopoly right over his or her own work, but competes in a broader market of copyrighted material. The grant of copyright protection permits the authors to stop users free-riding; and 
hence a market is created. As a result, Q1 copies of the good are sold and produced at P1.

If the formation of a copyright collecting society results in an effective monopoly over distribution, the result will be increased prices and a restriction in distribution. In Figure 1 the introduction of monopoly results in the number of works sold falling from $\mathrm{Q} 1$ to $\mathrm{Q} 2$, while consumers are forced to pay more (P2 minus P1). This has two principal effects. First, there is a transfer to the collecting society (and hence the authors) from consumers equal to (P2 minus $\mathrm{P1}$ ) multiplied by Q2. Second, there is a welfare loss to society because some consumers who value the work above what they would have paid in a competitive market (P1) do not value the work sufficiently to purchase it at the monopoly price (P2). This results in a welfare loss equivalent to the shaded triangle.

\section{Figure 1}

\section{Supply of and demand for copyright protected goods}

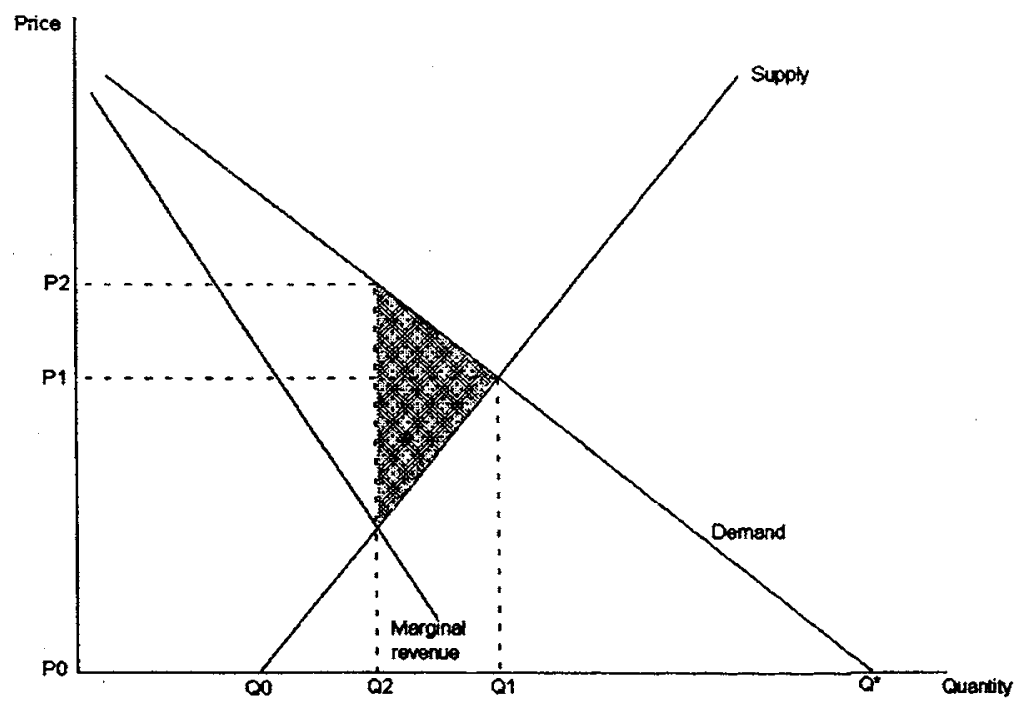

Though a stylised example, Figure 1 demonstrates that there are social benefits to encouraging competition in the distribution of copyrighted works, and as a corollary, there are costs in allowing copyright collecting societies to operate as monopolies in the distribution of copyrighted material.

\section{Defects of the Present Regulatory Regime}

The Copyright Tribunal sets copyright licence fees. Under the Copyright Act 1968, the Copyright Tribunal has the power to hear disputes about terms and conditions 
of licences or licence schemes administered by collecting societies. Licensors, hcensees and persons desiring a licence may refer disputes to the Tribunal for determination. ${ }^{2}$ In this way:

The Copyright Tribunal is an arbitrator. It arbitrates disputes concerning the amounts which should be paid by way of reasonable or equitable remuneration under licences granted, or to be granted, sometimes by statute, for the use of copyright material. (Shepherd, 1995:1)

The Tribunal has been used in such a manner only 14 times since 1968 (ACCC, $1996: 8$ ), presumably because the proceedings are thought to be expensive, slow and unnecessarily legalistic (Simpson, 1995:254).

The anti-competitive behaviour of collecting societies is regulated by the Australian Competition and Consumer Commission (ACCC) under the Trade Practices Act (TPA). The TPA attempts to accommodate the different emphases adopted by intellectual property laws and competition policy. Sub-section 51(1) states that anti-competitive conduct permitted under intellectual property legislation is subject to the TPA. This blanket coverage is subject to sub-section 51(3), which provides an exception to the prohibitions contained in Part IV, except for sections 46 and $46 \mathrm{~A}$ (misuse of market power) and 48 (resale price maintenance). ${ }^{3}$ Significantly, however, the ACCC has the power to authorise otherwise anti-competitive conduct where the anti-competitive effect is outweighed by the public benefit (subsection 90(6)).4

This dual enforcement approach is limited in two fundamental respects. First, the Tribunal is purely reactive. It relies on parties to bring disputes brought before it (which happens often after many years of protracted and expensive negotiation), and does not have any powers to regulate to avoid disputes. ${ }^{5}$ Second, the Tribunal does not examine the anti-competitive or public interest effects of any licensing arrangement. ${ }^{6}$

The separation of the price-setting function from an explicit assessment of competition in the market, particularly when the market's existence is made feasible only by the legislative grant of market power, is inconsistent with the treatment of firms in other industries which enjoy significant market power. For example, such firms are often regulated in a manner that combines the price-setting function with consideration of actual or potential anti-competitive conduct. Examples include prices surveillance under the Prices Surveillance Act 1983 and industry-specific access/pricing regulation.

2 The Tribunal's jurisdiction and procedures are explained in ACCC (1996:8-12).

${ }^{3}$ See Thorpe (1995) for further details.

${ }^{4}$ See TPC (1991:11-13).

${ }^{5}$ However, a former President of the Tribunal acknowledges that the Tribunal is a de facto industry price setter and has an obligation to look beyond the matter before it to consider the consequences of its decisions in the wider marketplace (Shepherd, 1995:10-11).

6 WEA Records v Stereo FM(1983) 48 ALR 11. 


\section{Overcoming the Inadequacies of the Law}

Some options for overcoming these inadequacies are explored below.

Extending the Tribunal's power to regulate collecting societies. One option is to expand, and in the process clarify, the jurisdiction of the Copyright Tribunal.

The first step would be to change the Tribunal's reach and fundamental approach. Its reach can be extended by providing it with an arbitration role, and its focus extended to incorporate a specific public-benefit type ${ }^{7}$ or competition-related test (either in conjunction with, or in place of, the current 'reasonableness' test).

Care needs to be taken to ensure that any such extension of the Tribunal's jurisdiction is effective and does not create new distortions. For example, compulsory supervision and arbitration would be prohibitively expensive for many small participants.

Potential problems associated with the expansion of the Tribunal's role can be minimised by the establishment of a set of principles to ensure that licensing arrangements are used to further anti-competitive ends. Such a set of guidelines has been suggested by Lupton and Drahos (1996:12):

- $\quad$ the licensing scheme must be the least restrictive possible;

- the arrangements should not discourage direct dealings between creator and user;

- the fee should accord with the amount of material used;

- if blanket licences are necessary, they must have carve-out provisions, which provides a mechanism for authors to have control over selected works rather than giving absolute authority to collecting societies.

- the person who decides which material to use should be, where possible, the person who negotiates and pays for the licence;

- $\quad$ licence rates should not differ between equivalent users;

- all users should have unrestricted and automatic access to the societies' published licence terms;

- the membership input agreements should not exclude the member's ability to licence directly;

- membership of the society should not be restricted; and

\footnotetext{
${ }^{7}$ For example, sub-section $90(6)$ of the TPA.
} 
- licence terms should not extend beyond the rights protected by the copy right of the societies' members.

While some of these elements have been unilaterally adopted by societies, and others required by the $\mathrm{ACCC}$ in the context of authorisations, a more transparent process would be ensured if they were incorporated in legislation.

Given that the United States has a broadly similar scheme to that advocated above (ACCC, 1996:29-30, 85; Schlesinger, 1989:85), it would be difficult, although not impossible, for it to oppose the introduction of such a scheme. Equally, such an approach appears to be consistent with clause 2 of Article 40 of the international TRIPs Agreement (1994):

Nothing in this Agreement shall prevent Members from specifying in their national legislation licensing practices or conditions that may in particular cases constitute an abuse of intellectual property rights having an adverse effect on competition in the relevant market. As provided above, a Member may adopt, consistently with the other provisions of this Agreement, appropriate measures to prevent or control such practices, which may include for example exclusive grantback conditions, conditions preventing challenges to validity and coercive package licensing, in the light of the relevant laws and regulations of that Member.

Reforming the Tribunal's price-setting function. The Tribunal's approach to pricing has been relatively controversial (Court, 1987:368-72).

The task facing the Tribunal is far from easy. A former President of the Tribunal, Justice Shepherd, has described the process of determining a price, particularly when employing the 'notional bargaining approach', ${ }^{8}$ in these terms:

The Tribunal's task is one of evaluation or estimation. ... The starting point will be a search for a market. If there is a market, probably the market value will be the value which prevails. If there is no market, or if the object ... is not well sought after so that comparable sales are not easily found, the court will have to construct or endeavour to construct, a notional buyer. This becomes a much more theoretical exercise. It involves a degree of subjective judgement and minds will often differ as to what the appropriate outcome is.

The Copyright Tribunal is almost invariably faced with a task of this kind. It is unlikely that there will be a market for a particular right which is involved. If there is not, the Tribunal usually tries the 'notional bargaining approach', constructing, as best it can from the available material, the factors and considerations which it con-

\footnotetext{
${ }^{8}$ See Spencer v The Commonwealth (1907) 5 CLR 418 at 432, per Griffith CJ.
} 
siders the parties themselves would consider if they were entering into such a bargain (Shepherd, 1995:8-9).

Concern has been expressed that the Tribunal has at times been inconsistent in administering this approach, vacillating between setting prices based on use and prices based on compensation for forgone sales (Court, 1987:368).

While the Tribunal's decisions are acknowledged to be value judgments, ${ }^{9}$ there is a clear appreciation of the economic forces of supply and demand substitution and cross-elasticities:

In the background is the anxiety that the figure, if too high and thus unfair, may operate adversely because it may paradoxically deny to the authors the remuneration s.53B intended them to have and also deny to educational institutions the ability to use as wide a range of material as they should. All in all the task is a most difficult and responsible one. ${ }^{10}$

While this passage implicitly acknowledges the importance of understanding economic forces (such as the cross-elasticity of demand) when setting licence fees, the Tribunal appears to lack the economic expertise to evaluate those forces adequately.

An obvious answer to the Tribunal's inexperience at price setting is to provide it some expert assistance. One solution is to appoint the ACCC as an amicus curiae (a friend of the Tribunal) to assist the Tribunal with the determination of the price. Another solution is to abolish the Copyright Tribunal and vest its responsibilities with the Australian Competition Tribunal. The benefit of this approach is threefold: the Australian Competition Tribunal has significant experience in dealing with complex competition-related matters; it is experienced in dealing with the ACCC as an amicus curiac, ${ }^{11}$ and it exposes copyright-related practices to the scrutiny of an organisation that is less susceptible to regulatory capture.

A case for temporary prices surveillance? Yet another option is to subject the collecting societies to prices surveillance by the ACCC. The Industry Commission has proposed a simple test to determine when prices surveillance is an appropriate mechanism. It recommends that surveillance should be limited to cases where a single firm has a greater than two-thirds market share and has no major rival; and faces sporadic or trivial imports (import penetration persistently below ten per cent of the market); and is sheltered by substantial barriers to entry (including the expansion of rivals) (IC, 1994:80).

In this case, whether price surveillance is appropriate for collecting societies turns on the market definition(s) adopted. While the ACCC (1996:66-7) has reached no firm opinion on the appropriate market definition for collecting socie-

${ }^{9}$ Copyright Agency Ltd v Department of Education of New South Wales (1985) 59 ALR 172 at 183, per Shepherd J.

${ }^{10}$ Id at 201, per Shepherd J.

11 Indeed, the Australian Competition Tribunal may be too close to the ACCC (Thorpe, 1997). 
ties, its observations suggest that collecting societies satisfy the Industry Commission's checklist, and are hence suitable for prices surveillance.

Given that prices surveillance is a second-best policy measure, it may best be used a transitory policy measure until collecting societies have a more appropriate regulatory regime.

\section{Concluding Comments}

The concerns raised by small business regarding the collective exploitation of copyright should not be viewed as a problem that 'needs fixing'. Such an knee-jerk approach would result in (further) piecemeal amendment to the Copyright Act 1968, and possibly introduce new distortions in the process.

It may, however, be too late; in response to the concerns raised before the HRSCLCA, the Australian Performing Rights Association (APRA, 1997) has agreed to support legislative amendments to exempt radio listeners from any liability for copyright licences. The exemption, however, asks that the Copyright Tribunal, in effect, pass the forgone royalties on to radio broadcasters.

Policy-makers should view such business concerns as being charged for listening to the radio at work merely as a symptom of a much deeper problem. That problem is the inadequate regulation of the market power granted to copyright owners and exploited by the collecting societies (ACCC, 1996:1). As this article has demonstrated, there is significant scope for improving the regulatory regime.

While the National Competition Policy reform process has focused on monopoly power and access issues in major infrastructure industries, it appears to have overlooked the same issues with respect to intellectual property. It is time to subject intellectual property, a major input in an on-line information-based economy, to similarly rigorous analysis. 


\section{References}

Australian Competition and Consumer Commission (ACCC) (1996), Draft Determination - Applications for Authonisation and Notification: Australasian Performing Right Association, Authorisation Nos A30166 to A30173 \& N 30714, File Nos CA95/26 to CA95/33 \& CN95/17, 16 October.

Australian Performing Rights Association (APRA) (1997, Copynight Royalties for Music Played by Small Business: APRA Position Paper, 27 October, submission 171 to the House of Representatives Standing Committee on Legal and Constitutional Affairs Inquiry Into Copyright Royalties For Music Phayed By Small Business, Canberra.

Clode, D. (1998), 'Power to the Artist: The False Promise of Moral Rights', Agenda 5: 123-32.

Council of Australian Governments (COAG) (1995), Competition Principles Agreement, Canberra (February).

Court, J. (1987), 'The Notional Bargain Approach to the Determination of Equitable Remuneration for Compulsory Licences: A Comment on Four Decisions of the Copyright Tribunal', Sydney Law Review 11: 348-73.

Dnes, A. (1996), The Economics of Law, International Thomson Business Press, London.

Drahos, P. (1996), A Philosophy of Intellectual Property, Dartmouth, Aldershot.

Hadfield, G. (1992), The Economics of Copyright: An Historical Perspective, American Society of Composers, Authors and Publishers, Columbia University Press, New York.

Hilmer, F. (1993), National Competition Policy, AGPS, Canberra.

House of Representatives Standing Committec on Legal and Constitutional Affairs (HRSCLCA) (1997a), Copyright Royalties for Music Played by Small Business: Inquiry Information Booklet, Canberra, August.

(1997b), Inquiry Into Copyright Royalties For Music Playcd By Small Business: Submissions, vols $1-3$, Canberra.

Industry Commission (IC) (1994), What Future for Price Surveillance? A Submission to the Prices Surveillance Authority's Review of Declarations Under the Prices Surveillance Act 1983, AGPS, Canberra.

Lester, D. \& S. Faulder (1989), 'Survey of Collecting Socicties', pp. 108-59 in D. Pepperkorn \& C. van Rij (eds), Collecting Societics in the Music Business: Reports Presented at the Meeting of the International Association of Entertainment Lawyers, Maklu Publishers, Apeldoorn.

Lupton, P. \& P. Drahos (1996), 'Copyright Collecting Societies: Towards a Regulatory Balance of Public and Private Interests - A Response to the Simpson Report', Australian National University, August.

Matsuoka, S. (1989), 'Copyright Law and the Collecting Societies in Music in Japan', pp. 50-3 in D. Pepperkorn \& C. van Rij (eds), Collecting Societies in the Music Business: Reports Presented at the Meeting of the International Association of Entertainment Lawyers, Maklu Publishers, Apel-
doorn. 
Office of Regulation Review (ORR) (1995), An Economic Analysis of Copynight Reform: A Submission to the Copynght Law Review Committee's Review of the Copynight Act (Cth) 1968, AGPS, Canberra.

Schlesinger, A. (1989), 'Collecting Societies and United States Anti-trust Law', pp. 85-90 in D. Pepperkorn \& C. van Rij (eds), Collecting Societies in the Music Business: Reports Presented at the Meeting of the International Association of Entertainment Lawyers, Maklu Publishers, Apeldoorn.

Shepherd, I. (1995), 'Copyright Tribunal', unpublished paper.

Simpson, S. (1995), Review of Australian Copyright Collecting Societies: A Report to the Minister for Communications and the Arts, Commonwealth of Australia, Canberra.

Thorpe, J. (1995), 'In Defence of Intellectual Property Tie-ins', Corporate and Business Law Journal 8(1): $81-92$.

- (1997), 'Bias and the Australian Competition Tribunal', Trade Practices Law Journal 5: 148-53.

Trade Practices Commission (TPC) (1991), Application of the Trade Practices Act to Intellectual Property, AGPS, Canberra.

Treasury (1996), 'The Economic Role of Copyright', Economic Roundup (Autumn): 55-75.

TRIPs Agreement (1994), Agreement on Trade-nelated Aspects of Intellectual Property Rights, including Trade in Counterfeit Goods, part of World Trade Organisation Agreement 1994, Final Act of the Uruguay Round of Multilateral Trade Negotiations, Marrakesh, 15 April. 